\title{
Study on the Curriculum of Sports Law for the Major of Physical Education in China
}

\author{
Jianxin Gao \\ Jiangxi Teachers College, Yingtan, Jiangxi, China \\ gaojianxin1985@126.com
}

Keywords: Sports Law, Course Setting, Governed by law

\begin{abstract}
With the announcement of the Central Committee of the Communist Party of China on the fourth Plenary Session of the 18th CPC Central Committee, the decision of the Central Committee of the Communist Party of China on comprehensively promoting major issues of rule by law, China's strategy of administering the country according to law was established. Under the background of building a socialist country ruled by law with Chinese characteristics, the development of sports of athletics, physical education and mass in China is bound to be institutionalized. It is an inevitable trend to achieve rule by law. The college students of sports education are the future and hope of the development of the sports cause in China. How to promote sports in university sports major teaching, improve the legal consciousness of students majoring in physical education, the professional sports college students understand the construction of sports in the law, the sports law can make the physical sense of law and regulations applied to physical education, sports training, sports competition, sports fitness and sports industry practice to the construction of sports law subject is particularly important. Based on the rights and obligations in sports, this paper studies the curriculum of sports law with the methods of literature, interview, case study and theoretical analysis. Study from the aspect of law theory based on the concept of sports law, sports law characteristics, origin of sports law, sports law, the principles of sports law, sports law system of sports laws and regulations are summarized, followed from the substantive law and the procedural law of the Sports Law Curriculum research, to promote the popularity of sports law and consciousness in professional sports university students, and provide a theoretical reference for the construction of sports law subject.
\end{abstract}

\section{The purpose}

With the complexity, enlargement and professional development in the world sports phenomenon, the relationship between sports and law is becoming more and more closely. Nowadays, the sports legal system in the developed countries is relatively perfect, and the construction of the discipline of sports law in China is still in its infancy. The promulgation of the "Sports Law of the People's Republic of China" in 1995 marked that our sports industry was brought into the orbit of legalization, and there were laws to follow in the process of sports development. However, because of the late construction of the sports legal system in China, the legal consciousness of the majority of the sports workers is weak, which seriously hinders the development of sports law in China. In order to improve the legal awareness of sports majors and improve the construction of sports law curriculum as soon as possible, it is particularly important to study the curriculum of sports law.

\section{The necessity of setting up the course of Sports Law}

In the field of competitive sports, with the development of the sports occupation, business in China, the 2008 Beijing Olympic Games, the 2010 Guangzhou Asian Games, the 2014 Youth Olympic Games in Nanjing, F1, Shanghai Tennis Masters, the net, the women's World Cup and other international events and games, super CBA, individual Championships and other international sports events the success of sports events in China presents a multi-level, multi regional development trend. 
According to incomplete statistics, every year China's sports club due to lack of sports laws and regulations, the loss in sports law in the litigation amount is huge, is the lack of a large number of domestic sports professional who not only understand the professional knowledge of sports but relevant laws. In the field of large sports events, more and more domestic and inter national events inevitably fall into the legal disputes arising from sports events. The legal contract disputes of sports events involve a wider range and more specialized, without the guarantee of sports law, and sports events can not be carried out in an orderly way.

In terms of physical education in school, with the increasing awareness of laws and regulations in recent years, school physical education injury accidents have become the main problem of school sports legal disputes and lawsuits. The legal disputes between the various legal subjects such as parents, sports teachers, schools, sports equipment manufacturers and other legal subjects are increasing. In the school sports injury disputes, the legal responsibility identification has become the main problem of the school sports legal disputes. In the solution of school sports disputes, under normal circumstances, schools become the main subject of responsibility, and schools at all levels are afraid of injuries caused by sports disputes. The school sports disputes have seriously affected the development and orderly conduct of school sports in our country. Therefore, because of fear of responsibility, the intensity, time limit and content of physical education teachers have changed significantly, and the intensity has not reached, which has seriously affected the development of students' physical fitness in China. Therefore, the occurrence of injury accidents in school sports is not terrible, the serious problem is that the responsibility for the injury accident is not clear, and there is no relevant law to define.

With the continuous deepening and development of the 121 project of the national fitness program and the national fitness regulations, China's social sports have been developing booming. But the sports legal disputes caused by social sports activities are also increasing. For example, the problem of public injury in social sports, the infringement of amateur sports activities and so on. The legal disputes arising from these social sports fields are the legal disputes which have not been touched by the civil law, the criminal law and the tort law. Therefore, the development of social sports in our country urgently needs the standard of sports law.

In China most sports college students have poor cultural achievements in the college entrance examination, which affects their understanding of the laws and regulations of sports in the future. Therefore, in order to overcome the current situation of poor physical education students' cultural achievements, it is necessary to set up elective courses or specialized courses in sports laws and regulations in all kinds of college sports majors. This has played an important role in understanding the laws and regulations of sports majors.

\section{Research methods}

\subsection{Document}

Through related websites such as Jiangxi teachers college library, Yingtan library, sports information network and sports soft science network, we searched articles, treatises and research papers about university sports law courses, and collected the documents and materials needed for this topic. The research group collects more than 100 articles to provide theoretical support for the research.

\subsection{Case research}

According to the research needs, the research group according to the Jiangxi teachers college sports law courses conducted a case study of sports law curriculum standards, teaching syllabus, set up the feasibility analysis of the professional teachers, students, teaching methods are analyzed.

\subsection{Expert interview}

In the course of the investigation, the author interviewed the experts of sports law in depth and collected various kinds of qualitative data to analyze and sum up. At the same time, the group interviewed the Yingtan Education Bureau and the leaders of the Sports Bureau. In view of the purpose and content of the research, we know about the current situation and existing problems of 
sports laws and regulations curriculum in interviews with experts and scholars in sports laws and regulations.

\subsection{Jurisprudential analysis}

The legal analysis of the results of the investigation was carried out. This study mainly analyzes the concept of physical education law course, and puts forward some pertinent suggestions.

\section{Concept}

\subsection{The concept of sports laws and regulations}

Sports laws and regulations refer to the general term for the adjustment of international, civil, criminal, administrative and other legal relations in the domestic sports world. The laws and regulations of sports have a broad and narrow sense. The broad sense of sports laws and regulations is the sports industry autonomy of the sports rules and regulations, statutes and so on. The narrow sense of sports laws and regulations includes international law and domestic law's legal concepts, legal norms, legal principles and so on, such as the sports code of the continental law system and the sports dispute case law of common law system. The amateur sports law of the United States and the People's Republic of China sports law of our country are the written sports code.

\subsection{The concept of sports laws and regulations}

The sports laws and regulations course is that in order to achieve the training law, sports related work of sports professional students in the law, and in the case of usage of sports laws and regulations textbook combined, it is reflected in the sports laws and regulations play in teaching content. At present, sports law courses in our country mainly includes two types: one is based on the Institute of physical education are prepared to use this kind of curriculum and teaching materials, teaching materials from competitive sports, mass sports, school sports and sports industry point of view, according to the idea of physical education teaching materials and Curriculum of sports law is designed and written; the other is the school of writing, the use of curriculum and teaching materials, the teaching materials from the angle of law of sports, including sports law concept, characteristics, origin, effect, scope and other aspects, and then from the sports curriculum classification of substantive law and procedural law: sports including the substantive law constitution. Civil and commercial law, criminal law, administrative law of sports; sports, sports programs including sports law arbitration law, procedure law, doping detection procedures.

\section{Countermeasures and suggestions}

\subsection{The compulsory course of the sports college}

We strongly appeal to the College of physical education to set up a compulsory course in sports law, and at least the elective course of sports law should be set up at least. At present, Jiangxi Teachers College Sports College School of sports law is not optimistic, suggest that the creation of sports law and other related lectures on Sports Law of advanced knowledge and case to explain and publicize, we can raise the interest and attract attention of students, so as to further open sports law courses.

\subsection{Reasonable arrangement of time}

The opening time of the course of sports law should be placed in the second semester of the sophomore year. In the first year of physical education, the students majored in physical education have already completed the two courses of law foundation and sports introduction. They have certain theoretical foundation for physical education and law.

\subsection{Strengthen the construction of the teaching staff}

Sports law curriculum requires very high teachers. Teachers not only need to know the knowledge of physical education, but also have a legal background. Teachers who can have two conditions at the same time are still lacking in physical education institutes, which affects the establishment of sports law curriculum. The establishment of a professional faculty is a necessary condition for the development of sports law. However, at present, students in law school do not understand sports. Therefore, the College of physical education should strengthen the training of sports law teachers 
who understand both physical education and legal background.

\subsection{To write the Physical Education Law Textbooks}

At present, there are more than ten teaching materials in the sports law circle. These materials are discussed from the sports law of sports science and law perspective in sports law circles by the acclaim. The above sports law textbooks can be used in sports law courses in Teachers College, but the research group finds that these textbooks are generally high level, which is not suitable for students in Physical Education Institutes of Teachers College. The College of physical education should write a physical education law textbook that students are interested in and understand. Pressure.

\subsection{Content of Sports Law}

The writing of the teaching contents of the laws and regulations of sports should pay attention to the actual situation of the students of the colleges and universities on the basis of the reference of the existing sports law textbooks. The teaching and research group compiles the teaching content of the sports law suitable for the school. Sports law teaching content should be less dry legal theory and many cases and case teaching, which can stimulate students' interest in sports laws and regulations.

\section{References}

[1] Guo Shu Li. A discussion on the pluralistic relief mechanism of sports disputes, [M]. Law Press, 2004.

[2] Han Yong. Research status of sports and sports law [M]. people's sports press, 2004.

[3] Huang Shixi. American university law school sports teaching status and Enlightenment of [J]. Journal of Shandong Sports Institute, 2005.21.

[4] Zhou Qingshan. The course of law school is set up in the course of sports law to discuss the theory and practice of [J]. contemporary education, 2012.4.

[5] High Rock. Sports law courses in Colleges and universities in China to set up the status quo and analysis of [D]. master degree thesis of Capital Institute of Physical Education, 2014.5.

[6] High Jianxin. A comparative study on Sports Law of China [J]. Journal of sports adult education, 2015.6. 